\title{
The RADMED monitoring programme as a tool for MSFD implementation: towards an ecosystem-based approach
}

\author{
J. L. López-Jurado ${ }^{1}$, R. Balbín ${ }^{1}$, F. Alemany ${ }^{1}$, B. Amengual ${ }^{1}$, A. Aparicio-González ${ }^{1}$, M. L. Fernández de Puelles ${ }^{1}$, \\ M. C. García-Martínez ${ }^{2}$, M. Gazá ${ }^{1}$, J. Jansá ${ }^{1}$, A. Morillas-Kieffer ${ }^{1}$, F. Moyá ${ }^{2}$, R. Santiago ${ }^{1}$, M. Serra ${ }^{1}$, and \\ M. Vargas-Yáñez ${ }^{2}$ \\ ${ }^{1}$ Instituto Español de Oceanografía, Centro Oceanográfico de Baleares, IEO, Palma de Mallorca, Balearic Islands, Spain \\ ${ }^{2}$ Instituto Español de Oceanografía, Centro Oceanográfico de Málaga, Fuengirola, Spain
}

Correspondence to: R. Balbín (rosa.balbin@ba.ieo.es)

Received: 1 April 2015 - Published in Ocean Sci. Discuss.: 6 May 2015

Revised: 17 September 2015 - Accepted: 4 November 2015 - Published: 18 November 2015

\begin{abstract}
In the western Mediterranean Sea, the RADMED monitoring programme is already conducting several of the evaluations required under the Marine Strategy Framework Directive (MFSD) along the Spanish Mediterranean coast. The different aspects of the ecosystem that are regularly sampled under this monitoring programme are the physical environment and the chemical and biological variables of the water column, together with the planktonic communities, biomass and structure. Moreover, determinations of some anthropogenic stressors on the marine environment, such as contaminants and microplastics, are under development.

Data are managed and stored at the Instituto Español de Oceanografía (IEO) Data Centre that works under the SeaDataNet infrastructure, and are also stored in the IBAMar database. In combination with remote sensing data, they are used to address open questions on the ecosystems in the western Mediterranean Sea.
\end{abstract}

\section{Introduction}

The term "fixed oceanographic stations" was defined as "oceanographic stations at which observations are taken continuously and periodically for periods of one year or more" (Landis, 2004). Operational oceanography (OO) can be defined as "the activity of systematic and long-term routine measurements of the seas and oceans and atmosphere, and their rapid interpretation and dissemination" (EuroGOOS, 2014). OO includes "a routine collection, interpretation and presentation of data from the ocean and atmosphere with the purpose of giving a reliable description of the actual conditions of the ocean including its living resources, establishing a marine database from which time series and statistical analysis can be obtained for descriptions of trends and changes in the marine environment including consequences for the living conditions in, on and around the sea and providing prognoses for the future developments of the conditions in the sea" (Buch and Dahlin, 2000). In general terms, systematic observation includes remote sensing facilities (satellite, radar, etc.) and local and in situ attended systems (moorings, ships of opportunity, regular research vessel cruises, etc.), together with autonomous or semiautonomous devices (sea level, buoys, drifters, gliders, profilers).

One example of a "fixed oceanographic stations" OO programme is California Cooperative Oceanic Fisheries Investigations (CalCOFI), a unique partnership of the California Department of Fish and Wildlife, the NOAA Fisheries Service and the Scripps Institution of Oceanography. CalCOFI conducts quarterly cruises off southern and central California, collecting a suite of hydrographic and biological data on the station and underway (Bograd et al., 2003; McClatchie, 2013). Examples in the Mediterranean Sea are the DYFAMED time-series site (Marty, 2002) that, even though it is a single station, forms part of the recently implemented Mediterranean Ocean Observing System on the Environment (MOOSE, http://www.moose-network.fr/), and also the HYDROCHANGES programme (Schroeder et al., 2013).

The Marine Strategy Framework Directive (MSFD) adopted in July 2008 (DIRECTIVE 2008/56/EC) aims at achieving or maintaining a Good Environmental Status 
(GES) by 2020 at the latest. It is the first legislative comprehensive instrument in relation to the marine biodiversity policy in the European Union (EU), as it contains the explicit regulatory objective that "biodiversity is maintained by 2020 " as the cornerstone for achieving GES. The decisions adopted by the EU authorities for the achievement of GES in the Mediterranean have to be based on appropriate scientific information resulting from the analysis of comparable data sets provided by sea-region-scale monitoring programmes. According to Article 11 of the MSFD, monitoring programmes shall be compatible within marine regions or subregions and shall integrate and complement the monitoring requirements imposed by other EU legislation, such as the Habitats Directive (92/43/EEC) and the Birds Directive (2009/147/EC), and international agreements such as the Regional Seas Conventions (RSCs). Consistency, coherence and comparability within marine regions and subregions should be ensured by coordination of monitoring methods in the framework of RSCs, also taking into account transboundary features and impacts (Zampoukas et al., 2012).

Proposals for developing coordinated monitoring programmes related to physical oceanography in the Mediterranean and Black seas have been recently presented by CIESM, such as "Designing MED-SHIP, a programme for repeated oceanographic surveys" (CIESM, 2012), or the "Continuous, long-term measurements of temperature and salinity of Mediterranean deep waters in key areas - a priority in the current context of global warming" HYDROCHANGES programme (Schroeder et al., 2013). They respond to an urgent necessity for coordinating efforts and taking advantage of synergies because, despite oceanographic monitoring having been carried out in the Mediterranean region by means of regular research vessel cruises in several areas, even following similar sampling protocols, there is still an important lack of coordinated monitoring at the Mediterranean scale.

The Instituto Español de Oceanografía, IEO, Observing System, IEOOS (Lavín, 2014), incorporates different observing systems, including deep moorings and surfacemeteorological moorings, tide gauge networks, a satellite reception station, the Argo-Spain network, regional oceanographic observatories, continuous R/V sampling systems, periodic R/V surveys, and modelling facilities. Within the framework of international scientific initiatives related to climatic change, the observation of the ocean and the conservation of the ecosystem (IGBP, GLOBEC, GOOS, OSPAR, etc.), the IEO has promoted the RADIALES programme (Valdés et al., 2002; Bode et al., 2012), as a structural activity, for the acquisition and analysis of regular temporary series of oceanographic data around the Spanish coasts. The multidisciplinary observations (physical, chemical, biological) are done in a timescale that sample oceanographic events in all the seasons of the year and successive years, which allows one to discriminate between the different variability sources. At the moment, the RADIALES programme comprises the longer series of multidisciplinary sampling for the study of oceanographic temporary series in Spain.

Included in the IEOOS in the Mediterranean Sea, RADMED project "series tempoRAles de Datos oceanográficos del MEDiterráneo" (time series of Mediterranean oceanographic data) was established by the IEO in 2007. It was designed to integrate previous monitoring programmes developed by different IEO centres along the Spanish Mediterranean coast (formerly ECOMALAGA, ECOMURCIA, ECOBALEARES and CIRBAL following the RADIALES philosophy), some of them running since the 90s. The RADMED project has unified techniques, sampling strategies and analyses to optimize them and to provide a modern and efficient operational oceanography system that produces the data demanded by the current oceanographic research as well as policy makers and other social demands. The main objective of this project focuses on the determination of a "reference environmental status of the sea" that will help to study the variability of physical, chemical and biological parameters, their oscillations and long-term trends. Another of the goals of the RADMED programme is to provide reliable information on the marine environment to managers and politicians as a tool to contribute to the marine system planning.

At present there are other programmes trying to establish the environmental status of the western Mediterranean Sea with an ecosystem perspective, like (but not only) the MERMEX programme (de Madron et al., 2011) or the LIONEX and ALBOREX experiments proposed as 2-year pilot actions under the PERSEUS project (www.perseus-net.eu), and proposals like the CIESM MED-SHIP already cited but not yet implemented.

The aim of this work is to present the RADMED monitoring programme to the Mediterranean scientific community to help and promote future collaboration in the development of the coordinated sea-region-scale monitoring programmes as required by the MSFD.

\section{RADMED scientific motivations}

The general circulation in the Mediterranean Sea is cyclonic along the continental slope (e.g. Millot and Taupier-Letage, 2005). Through the Strait of Gibraltar there is an inflow of surface Atlantic Water (AW) that spreads across the Alboran Sea and configures the Algerian Current. In the northwestern Mediterranean, the AW from the Algerian sub-basin joins with that coming from the Tyrrhenian Sea, configuring the Northern Current (NC), which flows along the continental slope. When it arrives in the Balearic sub-basin, it crosses the Balearic channels, while a branch of this current flows north-eastward along the northern slope of the Balearic Islands, giving rise to the Balearic Current (BC). See Fig. 1 for a graphical description of the main hydrographic and geographic features of the western Mediterranean Sea. 


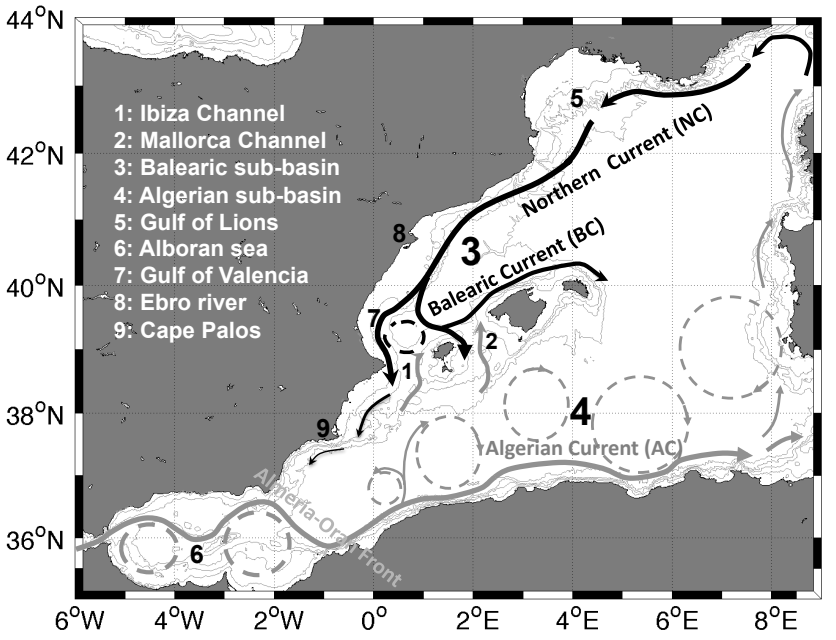

Figure 1. Western Mediterranean Sea and main currents characterizing the regional circulation. The Algerian, Northern and Balearic currents are shown as thick arrows, and the Algerian gyres are indicated as light dotted arrows. Light grey lines denote isobaths (100, 500, 1000, and $2000 \mathrm{~m}$ ).

Two water masses are found at intermediate depths, the Levantine Intermediate Water (LIW), formed in the eastern Mediterranean Sea, and the Western Intermediate Water (WIW) formed seasonally during winter convection processes in the Gulf of Lion over the continental shelf and the slope (e.g. Vargas-Yáñez et al., 2012). Western Mediterranean Deep Water (WMDW) is formed during deep winter convection events in the Gulf of Lion and the Ligurian Sea (MEDOC-Group, 1970). Intermediate and deep water masses reach the Balearic channels after circulating along the continental slope of the north-western Mediterranean. WIW is transported by the Northern Current (NC) into the Gulf of Valencia and the Ibiza channel between the end of the winter and beginning of the spring; however, it is not found at the Balearic channels every year (López-Jurado et al., 2008). Its presence in the Balearic channels at the beginning of the summer determines the regional circulation and the meridional position of the density front originated by the confluence of new AW (fresher and hotter), just arrived through the Strait of Gibraltar, and resident AW (saltier and colder), in the northern part of the western Mediterranean Sea, with important implications for the ecosystem (Balbín et al., 2014b, and references therein).

After the winter of 2005 an abrupt change in the WMDW was observed, with the appearance of a complex thermohaline structure that implied the contribution of different water masses (López-Jurado et al., 2005). This structure, denoted as the Western Mediterranean Transition (WMT) (CIESM, 2009), affected the whole western Mediterranean Sea. There is no agreement on the relative importance of the different deep water formation mechanisms that have caused this phenomenon. Nevertheless, it seems evident that the anoma- lies observed in the eastern Mediterranean Sea, the Eastern Mediterranean Transient (EMT) (CIESM, 2000), as in the western one, the WMT, are the result of factors such as the increase in the salinity in the Mediterranean Sea or the extreme winter forcing, very probably induced by climatic variability and indirectly by the climatic change.

It has been shown that not only the anthropogenic pressures, but also the environment variability and the hydrographic phenomena that generate deep water, as the cascading or deep convection events that occur in the Mediterranean, affect biological processes that occur in the whole water column and over the sea floor (e.g. Company et al., 2008; Guijarro, 2012; Rodríguez et al., 2013; Carbonell et al., 2014; Hidalgo et al., 2014), and therefore the marine resources and their exploitation.

The basic strategy of the RADMED monitoring programme is to sample seasonally areas where differences in the large-scale oceanographic conditions could be expected. This monitoring comprises productive areas such as the Alboran Sea, oligotrophic waters such as those to the north of Cape Palos and around the Balearic Islands, or areas of special biological interest such as those surrounding the delta of the Ebro River. Coastal, shelf and deep stations are sampled to get information on the shelf-slope gradient. Deep stations provide a description of the water column, including intermediate and deep water masses and their anomalies along the time. Sampling quarterly along the year allows one to filter out the seasonal cycle for the long-term climatic studies. It also allows the study of some seasonal phenomena such as the intermediate and deep water formation and transport, or the biological processes. It also enables the description of shelf-slope and latitudinal gradients in the biochemical distributions of the waters surrounding the Spanish coast.

\section{General sampling strategy and methodology}

Water column temperature, salinity, dissolved oxygen, fluorescence and turbidity are sampled with CTD (conductivity, temperature, and depth) equipped with additional sensors in every oceanographic station. Chlorophyll $a$ and inorganic nutrients along the water column are sampled using a carousel water sampler at standard depths. Carbon dioxide $\left(\mathrm{CO}_{2}\right)$ is the most important greenhouse gas, and the carbonate system in seawater plays an important role in the biogeochemical cycles and is intimately linked to the processes of photosynthesis and respiration. Therefore, $\mathrm{pH}$, total alkalinity and partial pressure of $\mathrm{CO}_{2}$ in air and surface water have been included in the RADMED sampling strategy since 2010. Phytoplankton and zooplankton are sampled by Niskin bottles and bongo nets to determine their biomass and taxonomic composition. The details of the exact sequence of works at each station and their positions are described in the RADMED protocols (at http://www.repositorio.ieo.es/e-ieo/ handle/10508/1762). 


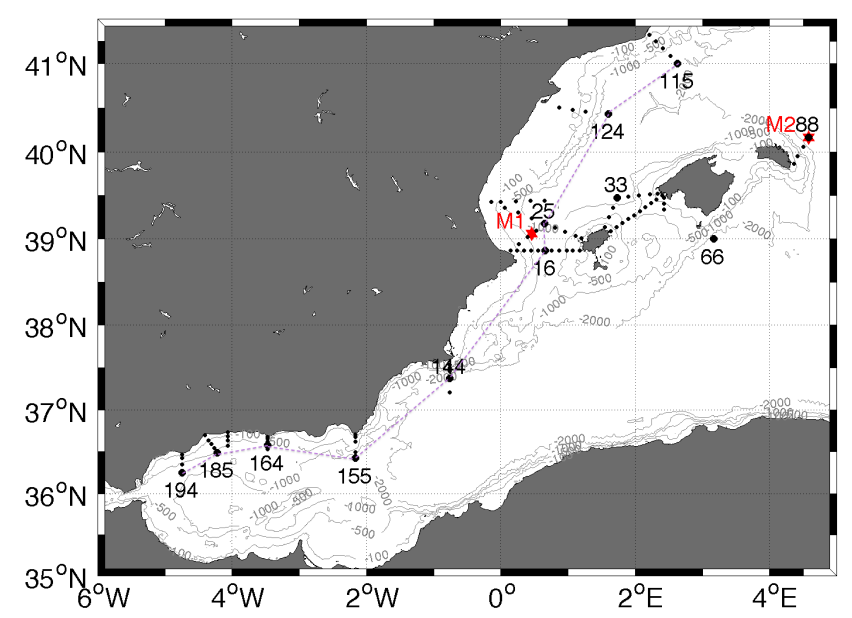

Figure 2. RADMED monitoring programme sampling stations. Thicker and numbered dots refer to deep stations used for water mass climatological studies. Red stars indicate the mooring positions. Light grey lines denote isobaths $(100,500,1000$, and $2000 \mathrm{~m})$.

\subsection{Geographical extension and temporal resolution}

The RADMED monitoring programme samples regularly every season a fixed distribution of stations, arranged on transects normal to the coast, alongside the Spanish Mediterranean coast, from Barcelona to the Alboran Sea and around the Balearic Islands. The stations' distribution is shown in Fig. 2.

\subsection{Hydrographic sampling}

Every station is sampled from the surface to the bottom. The hydrographic sampling is done using CTDs, mainly model SBE 911 and as spare instruments the models SBE 25 or SBE 19+, installed in carousel water sampler SBE 32. Additional sensors are connected to the CTDs. A SBE 43 sensor, a redesign of a Clark electrode sensor, is used to record the dissolved oxygen (DO). Fluorescence data, obtained with a WET Labs ECO fluorometer, measures the chlorophyll $a$ concentration that provides an indication of phytoplankton biomass (Cullen, 1982). The turbidity sensors used in these cruises are either transmissometer (Sea Tech Inc. and WET Labs C-Star) or optical back-scatter sensors (Seapoint).

The CTDs are lowered at an average speed of less than $1 \mathrm{~m} \mathrm{~s}^{-1}$. The salinity $(S)$, temperature $(T)$ and the DO, fluorescence and turbidity are derived using the Sea-Bird Electronics Data Processing routines following their recommendations, and they are finally binned every dbar. The sequence of routines used, their coefficients, and the methodology to calculate derived variables are described in chapter 6 of the RADMED protocols. The conductivity and DO sensors are calibrated using the carousel water samples. Calibrations are performed for selected depths of the water column at least
Table 1. Characteristic values of potential temperature $(\theta)$ and salinity $(S)$ of the different water types and local values in the Balearic Sea (López-Jurado et al., 2008).

\begin{tabular}{lcc}
\hline Water mass & Values at origin & Local values \\
\hline AW & $15.0<\theta<18.0$ & $15.0<\theta<28.0$ \\
& $36.15<S<36.50$ & $36.50<S<37.50$ \\
Resident AW & $13.0<\theta<28.0$ & $13.0<\theta<28.0$ \\
& $37.50<S<38.30$ & $37.50<S<38.20$ \\
WIW & $12.5<\theta<13.0$ & $12.5<\theta<13.0$ \\
& $37.90<S<38.30$ & $37.90<S<38.30$ \\
LIW & $14.0<\theta<15.0$ & $13.0<\theta<13.4$ \\
& $38.70<S<38.80$ & $38.45<S<38.60$ \\
WMDW & $12.7<\theta<12.9$ & $12.7<\theta<12.9$ \\
& $38.40<S<38.48$ & $38.40<S<38.48$ \\
\hline
\end{tabular}

once per cruise, when it lasts less than a week, and are done at least at the beginning and at the end of the cruise, when it is longer. The spare CTD is cross-calibrated with the SBE911 using the carousel at least once every cruise. The DO determinations to calibrate the SBE 43 sensor are performed by the Winkler titration method (Strickland and Parsons, 1972) and by direct spectrophotometric of total iodine at $456 \mathrm{~nm}$ (Pai et al., 1993; Labasque et al., 2004). The DO uncertainty is estimated to be $\pm 0.1 \mathrm{mLL}^{-1}$. The salinity calibrations are done using a Guildline 8400 Autosal and uncertainty is estimated to be \pm 0.002 .

In addition to the water column sampling, since 2013, continuous surface sampling has been done with a SBE 21 SeaCAT thermosalinograph that determines sea sub-surface (pumped-water) salinity and temperature.

An Airmar PB-200 weather station provides wind speed and direction, atmospheric pressure, temperature and humidity.

\subsection{Biochemical sampling}

Biochemical sampling is done using the carousel water sampler at standard depths that are "surface", 10, 20, 50, 75, 100, 200, 300, 500, 700, and $1000 \mathrm{~m}$, "deep chlorophyll maximum" (DCM), and "bottom". The DCM is always observed above $100 \mathrm{~m}$ in depth. These standard levels may be modified below $100 \mathrm{~m}$ to sample the core of intermediate water masses, the Western Mediterranean Intermediate Water (WIW), at around 100 to $200 \mathrm{~m}$, and the Levantine Intermediate Water (LIW), between 300 and $500 \mathrm{~m}$. The potential temperature $(\theta)$ and salinity $(S)$ used to define the core of the different water masses are shown in Table 1. Occasionally, up to three levels are sampled at the bottom if the water masses due to the WMT are detected, to characterize the "old", the "new" and the "cascading" WMDW (CIESM, 2009).

The samples obtained with the carousel are analysed for chlorophyll $a$, nutrients, $\mathrm{pH}$, alkalinity and phytoplankton abundance. The $\mathrm{pH}$ and alkalinity samples are collected from 
the carousel of Niskin bottles at standard depths after sampling for DO calibrations. The $\mathrm{pH}$ samples of seawater are collected in a clean borosilicate glass container and immediately measured using a glass/reference electrode cell (Dickson and Goyet, 1994). Alkalinity samples are also collected in a clean borosilicate glass container. Samples are treated with mercuric chloride to poison them, preventing further biological activity, and the container is closed to prevent any further exchange of $\mathrm{CO}_{2}$ or water vapour with the atmosphere. Samples are analysed by the potentiometric seawater alkalinity determination with two final end points (Dickson et al., 2007) with an automatic potentiometric titrant (Titrando model 808 Metrohm). After that, the nutrients samples are collected using $12 \mathrm{~mL}$ vials that are kept frozen at $-20^{\circ} \mathrm{C}$ until they are analysed in the laboratory. Nitrate, nitrite and silicate concentrations are determined according to the method of Armstrong et al. (1967), modified by Grasshof (1969). Phosphate concentrations are determined by the method of Treguer and Le Corre (1975). All these methods are adapted to oligotrophic waters and analyses are performed with a Technicon Autoanalyzer AAII and QuAAtro Marine of SEAL Analytical.

One-litre water samples from the carrousel taken at standard depths down to $100 \mathrm{~m}$ are filtered through a Whatman filter $\mathrm{GF} / \mathrm{F}$ and kept frozen at $-20^{\circ} \mathrm{C}$ until they are analysed by fluorometry (Holm-Hansen et al., 1965) using a Turner $10 \mathrm{AU}$ spectro-fluorometer previously calibrated with reference chlorophyll $a$ extract for chlorophyll $a$.

Sea surface $\mathrm{CO}_{2}$ partial pressure is measured in a flowing stream of seawater that is obtained by pumping surface seawater from the bow of the ship for underway analysis (Dickson et al., 2007). This underway measurement is made by a SUNDANS (Surface UNderway carbon Dioxid partial pressure ANalySer) system.

\subsection{Biological sampling}

The phyto- and bacterio-plankton abundance samples are collected from the carousel water sampler using standard bottles $(125 \mathrm{~mL})$ for microphytoplankton and using cryovials $(5 \mathrm{~mL})$ for nano- and pico-plankton (bacterioplankton), at standard depths down to $100 \mathrm{~m}$. Micro-phytoplankton samples are treated with an acidified Lugol iodine solution and nano- and pico-plankton samples are treated with glutaraldehyde solution and immediately frozen in a liquid nitrogen container. Micro-phytoplankton samples are examined and analysed by inverted microscopy (LDMIL Leica) prior to the sedimentation procedure (Uttermöhl, 1958). Nano- and picoplankton abundances are performed (Shapiro, 1995) with a flow cytometer (FACScalibur, Becton and Dickinson). For bacterio-plankton analysis, a subsample was stained with a Syto-13 stain solution (Gasol et al., 1999).

Zooplankton samples are taken at across-shelf and slope to complete the characterization of the planktonic system, considering its biomass and taxonomic composition. Sam- ples are collected by a $20 \mathrm{~cm}$ mouth diameter bongo net fitted with 250 and $100 \mu \mathrm{m}$ meshes, performing oblique hauls from $100 \mathrm{~m}$ to the surface or from $5 \mathrm{~m}$ above the bottom to the surface if the station is shallower. The net is fitted with a flowmeter (General Oceanic model 2030) in order to measure the volume of filtered water. The $250 \mu \mathrm{m}$ sample is divided in two subsamples using a Folsom plankton splitter. One of the subsamples is preserved in $4 \%$ neutralized formaldehyde buffered with borax and used for taxonomic analysis. The other subsample is frozen at $-20^{\circ} \mathrm{C}$ and the zooplankton biomass determined following Lovegrove (1966). The same procedure is followed with the $100 \mu \mathrm{m}$ sample after filtering it onboard through a $250 \mu \mathrm{m}$ mesh to extract the larger mesozooplankton fraction, separating it from the smaller one.

\subsection{Data management}

All RADMED CTD and biogeochemical data are integrated into the IEO Data Centre (CEDO, Centro Español de Datos Oceanográficos) following standard procedures, and after that are incorporated into the SeaDataNet infrastructure (http://www.seadatanet.org/).

In parallel, all the CTD data, nutrients and chlorophyll $a$ are included in the IBAMar database. IBAMar is a regional database (Lopez-Jurado et al., 2014; AparicioGonzález et al., 2015) that brings together all the physical and biochemical data provided by multi-parametric probes and water samples taken during the cruises managed by the Balearic Oceanographic Centre of the Instituto Español de Oceanografía (COB-IEO) during the last 4 decades. Initially it compiled data from hydrographic profiles obtained from CTDs equipped with several sensors, but it has recently been extended to incorporate data obtained with hydro casts using oceanographic Niskin bottles. The result is an extensive regional database that includes physical hydrographic data such as temperature, salinity, DO, fluorescence and turbidity, as well as biochemical data, specifically, dissolved inorganic nutrients (phosphate, nitrate, nitrite and silicate) and chlorophyll $a$. Independent teams had used different technologies and methodologies during the 4 decades of data sampling; however, for the IBAMar database, data have been reprocessed using the same protocols, and a standard quality control methodology has been applied to each variable. The result is a homogeneous and quality controlled data regional database. The IBAMar database at standard levels is freely available for exploration and download from http: //www.ba.ieo.es/ibamar/ (Aparicio-González et al., 2015).

Biological data (biovolume, zooplankton biomass, phytoplankton abundance and composition, nutrients, chlorophyll $a$ ) and some meteorological parameters are included in the IEO SIRENO (Seguimiento Integrado de los REcursos Naturales Oceánicos) database. The cruises metadata, also known as cruise summary reports (CSR), are systematically sent to the IEO Data Centre and are included in the global CSR database, currently linked to the European Infrastruc- 
ture SeaDataNet and also the POGO initiative (http://www. ocean-partners.org/). It gives visibility to the RADMED activity and also allows the IEO fulfil its international obligations.

The website of the IEO Mediterranean Group on Climate Change (MGCC, http://www.ma.ieo.es/gcc/) offers information about the IEO monitoring systems as well as useful products as statistics of temporal series and mean values of data that are also accessible. The information presented in this web is mainly addressed to the scientific community. Nevertheless, the MGCC also considers of great importance the scientific spreading to the general public, especially to students. For this reason, some activities and wide public information are also included in the website.

\subsection{Collaboration with other programmes}

The RADMED team has collaborated traditionally with different research national and international programmes, not only using its facilities and protocols, but also optimizing sailing time to develop opportunity measurements during the cruises. The routine sampling and the ship availability within the RADMED monitoring programme allow us to carry out more detailed studies within some areas with a special interest from a physical or ecological point of view. These studies are focused on processes occurring on different spatial scales than those monitored in the RADMED monitoring programme. Nevertheless, the RADMED monitoring programme provides an oceanographic framework for the correct interpretation of data collected within such projects. On the other hand, these specific projects provide additional information that can be incorporated into the RADMED databases establishing reciprocal benefits for both RADMED and the other projects. Examples of this collaboration are the DESMMON project (Desarrollo y Estudio de un Sistema de Monitorización multidisciplinar en el Mediterráneo Occidental) funded by the Spanish Ministry I+D+i plan, or the PERSEUS (Policy-oriented marine Environmental Research for the Southern European Seas) and IRIS-SES (Integrated Regional monitoring Implementation Strategy in the South European Seas) projects, funded by the EU 7th Framework Programme.

There is a general agreement on the long-term increase in $T$ and $S$ in the Mediterranean Sea (e.g. Schroeder et al., 2013), and phenomena like the EMT (CIESM, 2000) and the WMT (CIESM, 2009) also show how interannual variability can induce $T-S$ changes several times stronger than those associated with long-term changes. Systematic assessments of hydrological variability in relation to climate and to changes in biogeochemical processes and biodiversity are crucial to understanding the mode of response/functioning of the marine ecosystem (Company et al., 2008). For these reasons, the long-term monitoring of basic hydrographic parameters as temporal series with adequate temporal resolution (that means, with a sampling period that allows one to resolve all of the relevant scales) at strategic places of the Mediterranean Sea (like straits and channels, deep water formation areas and deep areas of the basins) are a priority in the context of global change (Schroeder et al., 2013). The HYDROCHANGES programme ("Continuous, longterm measurements of temperature and salinity of Mediterranean deep waters in key areas - a priority in the current context of global warming", https://en.wikipedia.org/wiki/ Transposition_(law)) has been presented by CIESM, as a proposal for developing coordinated monitoring programmes related to physical oceanography in the Mediterranean and Black seas. The HYDROCHANGES programme comprises an international network of deep moorings for the long-term monitoring of the hydrological variability in the Mediterranean Sea. The RADMED team has installed a new mooring within this programme whose purpose is to restore the Ibiza channel HYDROCHANGES mooring that was "temporarily interrupted" (http://www.ciesm.org/news/ciesm/040714. $\mathrm{htm}$ ) between March 2005 and June 2014. The mooring is placed on the continental slope in the north of the Ibiza channel, close to station 25 on the map of Fig. 2. It consists of an Aquadopp current meter and a SBE37 CTD at 18-20 m above the bottom. Maintenance is planned to be every 6 months during the first 2 years and then every year within the RADMED monitoring programme. Additionally, a second mooring will be installed in the next months in the NE of Menorca, close to station 88 on the map of Fig. 2. This mooring will install five current meters, eight CTDs and two sediment traps to study the WMT during 2 years, and after that it will be maintained as a classical HYDROCHANGES mooring keeping only one current meter and one CTD a few metres above the sea floor.

The RADMED team also collaborates with other monitoring strategies such as the TUNIBAL programme focusing on ichthyoplankton ecology around the Balearic Islands (Alemany et al., 2010).

\section{Main RADMED scientific results}

One of the main advantages of RADMED is that the sampling is always done over a regular grid. This fact helps the development of studies related to the annual cycles of different variables, their seasonal and interannual variability, the effects of winter convective processes, the presence of water masses, mesoscale structures, transport and exchange between basins, cycles, trends and possible climate changes, as well as environmental and ecological studies of species.

In this context, and among other studies, RADMED has allowed us to monitor the evolution of the deep waters thermohaline anomaly in the western Mediterranean Sea, first observed in 2005 (López-Jurado et al., 2005) and that now affects the whole western Mediterranean Sea. Figure 3 shows the temporal evolution of the potential temperature, $\theta$, versus salinity, $S$, at a deep station NE of Menorca (number 88 in the 


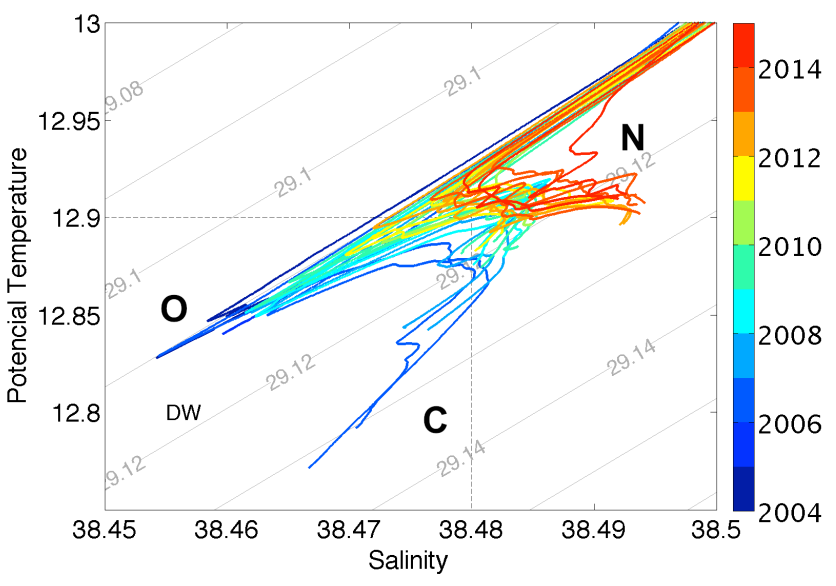

Figure 3. $\theta-S$ diagram at RADMED station 88 , at a depth of $2450 \mathrm{~m}$, NE of Menorca from 2004 to 2014. Grey lines represent isopycnals. The colour bar indicates the date when the station was visited.

map of Fig. 2) from 2004 (before the thermohaline anomaly) until nowadays. It is possible to observe the contribution of three water masses, the old WMDW, the "O" point that has been shifted upwards hundreds to thousands of metres by the new WMDW, the "N" point, and the waters that originated by cascading, the " $\mathrm{C}$ " point, which occupy the bottom of the water column (CIESM, 2009). This structure slowly evolved towards a saltier and warmer new deep water from 2005 to 2014 , while the density of the deep water anomaly increased from 29.11 to $29.12 \mathrm{~kg} \mathrm{~m}^{-3}$ during that period (see Fig. 3).

RADMED data have also been used to characterize the spatial distribution and the temporal variability of the different oceanographic variables along the Spanish Mediterranean Sea and around the Balearic Islands. As an example, Fig. 4 shows the $T, S$, DO, and fluorescence, from the Alboran Sea to Barcelona, along the Spanish Mediterranean coast during the RADMED-0309 cruise that was conducted during 20 days in March of 2009. The transect is drawn in broken violet line in Fig. 2. Although each radial perpendicular to the bathymetry is sampled on only 1 day, the duration of the cruise is too long for mesoscale synoptic evaluations along this transect, but it is enough for sub-basin analysis. Temperatures below $13{ }^{\circ} \mathrm{C}$ together with DO content above $5 \mathrm{~mL} \mathrm{~L}^{-1}$ in the Balearic Sea indicate the presence of WIW. There is a clear north-south gradient in surface salinity, with the higher values in the north, corresponding to resident AW, and the lower values in the Alboran Sea, corresponding to the recent AW coming from the Strait of Gibraltar. The Alboran Oxygen Minimum Zone (Packard et al., 1988) is clearly observed at the Alboran Sea stations at around $300 \mathrm{~m}$. Fluorescence at this time of the year is quite low everywhere, except for the stations at the Alboran Sea, where eventually upwelling episodes are observed.

Seasonal climatologies of temperature, salinity and DO were computed at selected stations of the RADMED moni-
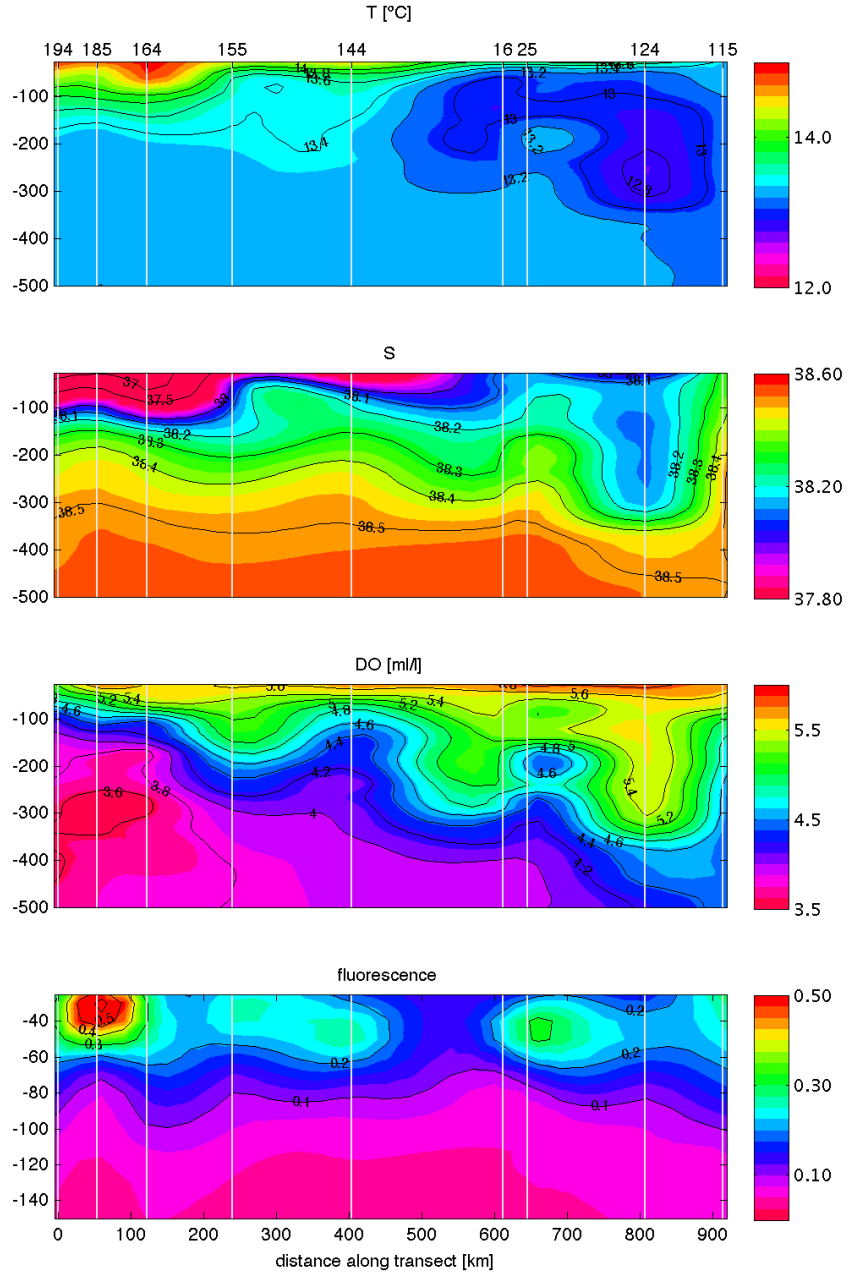

Figure 4. Temperature, $T$, salinity, $S$, dissolved oxygen, DO, and fluorescence along the Spanish Mediterranean coast during the RADMED-0309 cruise along the transect drawn in Fig. 2. Fluorescence data are shown only down to 150 dbar for clarity. Grey lines indicate station position and station numbers are shown at the top of the figure.

toring programme (Balbín et al., 2014a). Those climatologies reflect the appearance of WIW around the Balearic Islands in winter, spring and summer that the MEDAR-MEDATLAS climatologies (MEDAR-Group, 2002) do not show, due to the better temporal resolution of the RADMED sections.

MEDATLAS and RADMED data have been used to construct the longest temperature and salinity time series ever analysed in the western Mediterranean Sea (1900 to 2008) (Vargas-Yáñez et al., 2010). These time series show that both the upper and intermediate layers have warmed throughout the 20th century. Long-term and decadal variability in the upper layer correlate with surface air temperature in the Northern Hemisphere and heat absorbed by the upper North Atlantic Ocean, suggesting that the time series analysed in this 
work reflect the present heat absorption of the oceans in the context of global warming.

The RADMED data set has also helped the historical analysis of phenomena like the water mass transport through the Balearic channels (Heslop et al., 2012), the cascading processes in the western Mediterranean Sea (Puig et al., 2013), or the WIW formation processes (Vargas-Yáñez et al., 2012).

\section{Relevance of the RADMED monitoring programme for the MSFD requirements}

The MSFD outlines a transparent, legislative framework for an ecosystem-based approach to the management of human activities which supports the sustainable use of marine goods and services. The overarching goal of the directive is to achieve Good Environmental Status (GES) by 2020 across Europe's marine environment. The Commission Decision of 1 September 2010 (COM DEC; 2010/477/EU) lists criteria and indicators to assess GES for each descriptor of MSFD Annex I. Zampoukas et al. (2012) define monitoring under MSFD as the systematic measurement of biotic and abiotic parameters of the marine environment, with a predefined spatial and temporal schedule, in order to produce data sets that can be used to apply assessment methods and derive credible conclusions (with defined confidence) on whether GES is achieved or not for the marine area concerned. In this context, monitoring includes the choice of the parameters to measure, the sampling sites, the periodicity of sampling, the processing of the sample and the measurement of the parameter value. It does not include calculation of metrics and classification. In conclusion, monitoring should provide the data to allow assessment methods to classify a marine area as reaching or failing to reach GES.

The Ley de Protección del Medio Marino (Ley 41/2010) is the transposition of the MSFD to the Spanish legal system. It organizes the marine waters around Spain into five subregions, two of which, the Alboran Sea and the LevantineBalearic Sea, correspond to the western Mediterranean Sea and coincide with the working area of the RADMED monitoring programme. The documents relating to the implementation of the MSFD in Spain are available at the Spanish Ministry of Agriculture, Food and Environment (MAGRAMA) website: http://www.magrama.gob.es.

With regards to MSFD, Descriptor 7 (D7), "permanent alteration of hydrographical conditions does not adversely affect marine ecosystems", is specifically focused on the changes induced by human activities in ocean circulation, but the reference document of implementation of the MSFD in Spain explains that it is necessary to also take into account the changes in the hydrographical and hydrodynamical conditions at the scale of regions and subregions that are a combination of natural cycles and the climatic change. The MSFD does not explicitly indicate whether the climatic change and its effects have to be considered within the D7, but in Spain it has been decided to include it. In any case, the understanding of ocean dynamics is crucial also for interpreting the data obtained from almost any descriptor, and the physical and chemical characterization of the environment appears as transversal required information for any descriptor.

The RADMED monitoring programme is already conducting many of the evaluations required under the MSFD. The physical environment and the chemical composition of the water column that condition the primary production are regularly sampled. Primary producers are studied by microscopy, flow cytometry and total chlorophyll $a$ analysis. The photosynthetic activity and the respiration of organic matter together with the gas interchanges with the atmosphere determine the carbon cycle. The $\mathrm{CO}_{2}$ atmosphereocean interchange is one of the most important in the current context of climate change and is being sampled continuously using a SUNDANS system. The relations with the next trophic level can be estimated from the zooplankton studies. The higher trophic relations with zooplanktivorous and tertiary consumers are currently not being considered. The heterotrophic bacteria are essential for the decay of the organic matter to close the cycle and the study of bacteria is conducted by flow cytometry, as previously cited, distinguishing the type of bacteria depending on the amount of DNA. Finally, it would be very interesting to study the transference of organic matter to the benthos, and also the $\mathrm{CO}_{2}$ content of the sediment. The future implementation of this aspect by sediment traps installed in the HYDROCHANGES moorings or by dredges is under study.

The RADMED and RADIALES historical series have been incorporated into the report on Initial Assessment of the Current Environmental Status and GES in the Spanish waters whose conclusions are available at the MAGRAMA website, and both programmes are included in the Proposal of Monitoring Programmes as multipurpose platforms for the implementation of the MSFD in Spain. It is expected that they will provide information for D1, "Biological diversity is maintained" in Pelagic Habitats (PH), by the monitoring of planktonic groups over the continental shelves and in the open sea, giving information for the indicators on abundance and biomass, diversity indexes of planktonic components and changes in functional groups. They will also provide information on D4, "All elements of the marine food webs occur at normal abundance" for the indicators on phytoplankton production and biomass groups composition and spatial distribution of zooplankton in the platform and the open sea. D5, "Human-induced eutrophication is minimized", is also considered by the monitoring of $T, S$, nutrients, fluorescence, chlorophyll, DO, phytoplankton and transparency of the water column, giving information for many of the indicators in the platform and the open sea. Finally, D7, "Permanent alteration of hydrographical conditions", is also well characterized by the monitoring of $T, S$, fluorescence, DO, turbidity, $\mathrm{pH}$ and alkalinity and photosynthetically active radiation 
(PAR) at the water column and surface $p \mathrm{CO}_{2}$. In fact, all of those variables appear explicitly in Annex III, "Indicative lists of characteristics, pressures and impacts", of the MSFD. The Proposal of Monitoring Programmes for the implementation of the MSFD in Spain includes some annexes on the proposed sampling protocols and data analysis procedures, including automatic techniques coupled to imaging analysis procedures that will be implemented for the RADMED programme in coordination with the RADIALES programme.

There are other descriptors required by the MSFD that could easily be implemented within the RADMED cruises, like the study of microplastics in the open sea by Neuston nets or performing dredges at critical points to also characterize the sediment contaminants. In fact, there are plans to implement the sampling of microplastics as a pilot action within the ActionMed project (Ref. 006/HCMR-ActionMed of the ENV/MSFD Action Plans/2014) at critical points during 1 year using the RADMED cruises as an opportunity platform.

There are many programmes trying to determine the correct sampling period and spatial distribution of the stations of the monitoring programmes that have to fulfil the MSFD requirements. This is the objective of the IRIS-SES (Integrated Regional monitoring Implementation Strategy in the South European Seas) project where RADMED appears as a pilot action to implement $\mathrm{CO}_{2}$ and $\mathrm{pH}$ routine measurements and the HYDROCHANGES mooring line. The scientific results provided by the RADMED and RADIALES monitoring programmes together with the current knowledge of the system, the preliminary conclusions of the IRIS-SES project and the report on Initial Assessment of the Current Environmental Status and GES in the Spanish waters, suggest that the temporal resolution of the programme is enough for most of the data requirements, except for some critical points, to characterize the $\mathrm{PH}$ where the sampling frequency should be increased to a monthly periodicity as is done now in the RADIALES programme. In fact, the Baleares station off Majorca, still included in the RADMED network, was sampled every 10 days from 1994 to 2001 (de Puelles et al., 2004). It would also be necessary to improve the spatial distribution of stations to describe the main hydrographical features of water masses along the Spanish coast (Gulf of Valencia) and in the Alboran Sea (extending some of the present transects to the Alboran gyres and the Almería-Oran Front). The Gulf of Valencia was eventually sampled under the PERSEUS project with the aim of "detecting and complementing the data gaps".

The new monitoring technologies, which permit one to get synoptic information from large areas, as satellite images, or continuous recording of oceanographic parameters such as buoys or moorings that allow one to deal with the short-scale environmental variability, or automatic systems like the gliders, although they cannot sample all the environmental parameters over the whole water column, are also of outmost importance and should be considered as a very useful tool to compliment the information provided by the RADMED monitoring programme.

As indicated by Saraiva Nogueira and Armando Valladares (2012), “... our knowledge about the seas and oceans is rather limited. Future challenges, like climate change, cannot be assessed, nor can reasonable mitigation measures be taken without oceanographic data. Ocean services are expected to deliver on the promise of continuous forecasts of the state of the ocean environment. The knowledge needed for such forecasting capability cannot be obtained from research activities which are restricted in duration and project oriented. Scientific research has to be based on, and supplemented by, operational long-term ocean observations to provide analyses, predictions and other information products". From this perspective the RADMED monitoring programme is being a key tool for confronting these challenges. Right now, it is a programme not as exhaustive as the CalCOFI programme, but it provides regular and structured information that needs to be complemented by other programmes running in the Mediterranean Sea (including, but not only, MOOSE, Med-SVP, and ARGO floats). The purpose of the RADMED team is to coordinate with those programmes and make use of the new monitoring technologies to implement a monitoring service that is able to meet the MSFD requirements.

\section{Conclusions}

All the information obtained along the RADMED monitoring programme is being used to study the biological resources and their dependence on the physicochemical variables, the $\mathrm{CO}_{2}$ atmosphere-sea interchange and also physical effects like deep and intermediate water mass formation, modification and transport, and oscillations and trends in environmental variables.

The RADMED monitoring programme is already conducting many of the evaluations required under the MSFD Descriptors 1 (Pelagic Habitats), 4 (Trophic Chains) 5 (Eutrophication) and 7 (Hydrographical Conditions) along the Spanish Mediterranean coast from the shelf to the open sea.

Due to the sampling time pattern and the extensive spatial coverage, these surveys are suitable for gathering relevant information for other descriptors of the environmental state whose scales of time and spatial variability are similar. In particular, samplings might be also combined with the samplings necessary for the assessment of contaminants (Descriptor 8) and of marine litter (Descriptor 10).

In conclusion, the RADMED monitoring programme has been designed as a multipurpose platform that allows, depending on the research vessel available for the cruises, the implementation of any sampling method that could help to fill some of the gaps detected and reported in the Initial Assessment of the Current Environmental Status and GES in the Spanish waters. It is also a good platform to check new sampling technologies and to define new sampling protocols 
in the Mediterranean Sea, following the recommendations of the commission.

The new monitoring technologies, which permit one to get synoptic information from large areas, such as satellite imagery, or continuous recording of oceanographic parameters such as buoys or moorings that allow one to deal with the short-scale environmental variability, are also of outmost importance. It is necessary to remark on the usefulness of these new monitoring technologies and the monitoring facilities already existing in the Mediterranean Sea, which do not replace, but complement, traditional sampling surveys.

Finally, RADMED and equivalent programmes in the Mediterranean Sea could and should be coordinated and standardized to get a global view at basin scale.

Acknowledgements. We have to thank E. Tel for her very useful comments during the development of this paper. We have also to express our gratitude to L. Mortier and P. Testor, who sample the RADMED Menorca deep station, number 88, every time they have the opportunity within the MOOSE cruises or related cruises and the COB-IEO Group of Larval Ecology that samples both station 88 and the Cabrera deep station, number 66, every summer, if they visit the area. The RADMED monitoring programme is funded by the Instituto Español de Oceanografia, and has been partially funded by the DESMMON project (PN I+D+I CTM2008-05695C02-01), the PERSEUS project (FP7-287600) and the IRIS-SES project (FP7-07.0335/2013/659540/SUB/C2.), and will be partially funded from 2016 to 2018 by the ATHAPOC project (PN I+D+I CTM2014-54374-R). Some of the infrastructures involved have been funded by the European Fund for Regional Development under project Mejora del Equipamiento Científico-Técnico Para Estudios de Oceanografía Biogeofísica en Baleares (IEOC13-4E1844). Some of the instruments used during the cruises were made available to the RADMED programme by the Balearic Islands Coastal Observing and Forecasting System, SOCIB.

Edited by: A. Crise

\section{References}

Alemany, F., Quintanilla, L., Velez-Belchí, P., García, A., Cortés, D., Rodríguez, J. M., Fernández de Puelles, M. L., GonzálezPola, C., and López-Jurado, J. L.: Characterization of the spawning habitat of Atlantic bluefin tuna and related species in the Balearic Sea (western Mediterranean), Prog. Oceanogr., 86, 2138, 2010.

Aparicio-González, A., López-Jurado, J. L., Balbín, R., Alonso, J. C., Amengual, B., Jansá, J., García, M. C., Moyá, F., Santiago, R., Serra, M., and Vargas-Yáñez, M.: IBAMar Database: Four Decades of Sampling on the Western Mediterranean Sea, Data Science Journal, 13, 172-191, doi:10.2481/dsj.14-020, 2015.

Armstrong, F., Stearns, C., and Strickland, J.: The measurement of upwelling and subsequent biological process by means of the Technicon Autoanalyzer ${ }^{\circledR}$ and associated equipment, in: Deep Sea Research and Oceanographic Abstracts 3, 14, 381-389, Elsevier, 1967.
Balbín, R., López-Jurado, J. L., Aparicio-González, A., and Serra, M.: Seasonal and interannual variability of dissolved oxygen around the Balearic Islands from hydrographic data, J. Marine Syst., 138, 51-62, doi:10.1016/j.jmarsys.2013.12.007, 2014a.

Balbín, R., López-Jurado, J. L., Flexas, M. M., Reglero, P., VélezVelchí, P., González-Pola, C., Rodríguez, J. M., García, A., and Alemany, F.: Interannual variability of the early summer circulation around the Balearic Islands: driving factors and potential effects on the marine ecosystem, J. Marine Syst., 138, 70-81, doi:10.1016/j.jmarsys.2013.07.004, 2014b.

Bode, A., Lavín, A., and Valdés, L.: Cambio climático y oceanográfico en el Atlántico del norte de España, Instituto Español de Oceanografía, 2012.

Bograd, S. J., Checkley Jr., D. A., and Wooster, W. S.: CalCOFI: A half century of physical, chemical, and biological research in the California Current System, Deep-Sea Res. Pt. II, 50, 2349-2353, 2003.

Buch, E. and Dahlin, H.: BOOS Plan: Baltic Operational Oceanographic System 1999-2003, EuroGOOS Office, Southampton Oceanography Centre, 2000.

Carbonell, A., Tor, A., Álvarez-Berastegui, D., Vélez-Velchí, P., Dos Santos, A., Babín, R., and Alemany, F.: Environmental driving forces determining the epipelagic Decapod larval community distribution in the Balearic Sea (Western Mediterranean), Crustaceana, 686-714, doi:10.1163/15685403-00003316, 2014.

CIESM: The Eastern Mediterranean climatic transient, its origin, evolution and impact on the ecosystem, in: CIESM Workshop Monographs, edited by: Briand, F., 10, Trieste, 2000.

CIESM: Dynamics of Mediterranean deep waters, in: CIESM Workshop Monographs, 38, Malta, 2009.

CIESM: Designing Med-SHIP: a Program for repeated oceanographic surveys, in: CIESM Workshop Monographs, edited by: Briand, F., 43 (Supertar, Brac Island, 2011), 2012.

Company, J. B., Puig, P., Sardà, F., Palanques, A., Latasa, M., and Scharek, R.: Climate Influence on Deep Sea Populations, PLoS ONE, 3, e1431, doi:10.1371/journal.pone, 2008.

Cullen, J. J.: The deep chlorophyll maximum: comparing vertical profiles of chlorophyll a, Can. J. Fish. Aquat. Sci., 39, 791-803, 1982.

de Madron, X. D., Guieu, C., Sempéré, R., Conan, P., Cossa, D., D’Ortenzio, F., Estournel, C., Gazeau, F., Rabouille, C., Stemmann, L., Bonnet, S., Diaz, F., Koubbi, P., Radakovitch, O., Babin, M., Baklouti, M., Bancon-Montigny, C., Belviso, S., Bensoussan, N., Bonsang, B., Bouloubassi, I., Brunet, C., Cadiou, J.-F., Carlotti, F., Chami, M., Charmasson, S., Charrière, B., Dachs, J., Doxaran, D., Dutay, J.-C., Elbaz-Poulichet, F., Eléaume, M., Eyrolles, F., Fernandez, C., Fowler, S., Francour, P., Gaertner, J., Galzin, R., Gasparini, S., Ghiglione, J.-F., Gonzalez, J.-L., Goyet, C., Guidi, L., Guizien, K., Heimbürger, L.E., Jacquet, S., Jeffrey, W., Joux, F., Hir, P. L., Leblanc, K., Lefèvre, D., Lejeusne, C., Lemé, R., Loÿe-Pilot, M.-D., Mallet, M., Méjanelle, L., Mélin, F., Mellon, C., Mérigot, B., Merle, P.L., Migon, C., Miller, W., Mortier, L., Mostajir, B., Mousseau, L., Moutin, T., Para, J., Pérez, T., Petrenko, A., Poggiale, J.-C., Prieur, L., Pujo-Pay, M., Pulido-Villena, Raimbault, P., Rees, A., Ridame, C., Rontani, J.-F., Pino, D. R., Sicre, M., Taillandier, V., Tamburini, C., Tanaka, T., Taupier-Letage, I., Tedetti, M., Testor, P., Thébault, H., Thouvenin, B., Touratier, F., Tronczynski, J., Ulses, C., Wambeke, F. V., Vantrepotte, V., Vaz, S., and 
Verney, R.: Marine ecosystems responses to climatic and anthropogenic forcings in the Mediterranean, Prog. Oceanogr., 91, 97166, 2011.

de Puelles, M. L. F., Valencia, J., and Vicente, L.: Zooplankton variability and climatic anomalies from 1994 to 2001 in the Balearic Sea (Western Mediterranean), ICES J. Mar. Sci., 61, 492-500, 2004.

Dickson, A. G. and Goyet, C.: Handbook of methods for the analysis of the various parameters of the carbon dioxide system in sea water. Version 2, Tech. rep., Oak Ridge National Lab., TN (United States), 1994.

Dickson, A. G., Sabine, C. L., and Christian, J. R.: Guide to best practices for ocean $\mathrm{CO}_{2}$ measurements, vol. 3 of PICES Special Publication, North Pacific Marine Science Organization, 2007.

EuroGOOS: http://eurogoos.eu (last access: 9 November 2015), 2014.

Gasol, J. M., Zweifel, U. L., Peters, F., Fuhrman, J. A., and Hagström, Å.: Significance of size and nucleic acid content heterogeneity as measured by flow cytometry in natural planktonic bacteria, Appl. Environ. Microbiol., 65, 4475-4483, 1999.

Grasshof, K.: On an apparatus for simultaneous determination of 6 chemical compounds in sea water with digital and analogue output, vol. 20, Verlag Paul Parey Spitalerst. 12, 2000 Hamburg 1, Germany, 1969.

Guijarro, B.: Population dynamics and assessment of exploited deep water decapods off Balearic Islands (western Mediterranean): from single to multi-species approach, Ph.D. thesis, Universitat de les Illes Balears, Palma de Mallorca, 2012.

Heslop, E. E., Ruiz, S., Allen, J., LÛpez-Jurado, J., Renault, L., and TintorÈ, J.: Autonomous underwater gliders monitoring variability at "choke points" in our ocean system: A case study in the Western Mediterranean Sea, Geophys. Res. Lett., 39, L20604, doi:10.1029/2012GL053717, 2012.

Hidalgo, M., Reglero, P., Álvarez-Berastegui, D., Pérez-Torres, A., Álvarez, I., Rodríguez, J. M., Carbonel, A., Zaragoza, N., Tor, A., Goñi, R., M. S., Babín, R., and Alemany, F.: Hydrographic and biological components of seascape structure the meroplankton community in a frontal system, Mar. Ecol.-Prog. Ser., 505, 6580, doi:10.3354/meps10763, 2014.

Holm-Hansen, O., Lorenzen, C. J., Holmes, R. W., and Strickland, J. D.: Fluorometric determination of chlorophyll, J. Conseil, 30, 3-15, 1965.

Labasque, T., Chaumery, C., Aminot, A., and Kergoat, G.: Spectrophotometric Winkler determination of dissolved oxygen: reexamination of critical factors and reliability, Mar. Chem., 88, 53-60, 2004.

Landis, R.: The Development of Global Operational Oceanography: IGOSS the Foundation, in: JCOMM Technical Report, 27, 1-18, World Meteorological Organisation, 2004.

Lavín, A.: The Spanish Institute of Oceanography Observing System, in: 7th EuroGOOS conference: Operational Oceanography for Sustainable Blue Growth, 2014.

Lopez-Jurado, J., Aparicio-González, A., Babín, R., Alonso, J., Amengual, B., Jansá, J., García-Martínez, M., Moya, F., Serra, M., and Vargas-Yáñez, M.: IBAMar DATABASE: 4 decades sampling on the Western Mediterranean Sea, Instituto Español de Oceanografía, http://doi.pangaea.de/10.1594/PANGAEA.831923 and http://www.ba.ieo.es/ibamar, doi:10.1594/PANGAEA.828775, 2014.

López-Jurado, J. L., González-Pola, C., and Vélez-Belchí, P.: Observation of an abrupt disruption of the long-term warming trend at the Balearic Sea, western Mediterranean Sea, in summer 2005, Geophys. Res. Lett., 32, L24606, doi:10.1029/2005GL024430, 2005.

López-Jurado, J. L., Marcos, M., and Monserrat, S.: Hydrographic conditions affecting two fishing grounds of Mallorca island (Western Mediterranean): during the IDEA Project (2003-2004), J. Marine Syst., 71, 303-315, doi:10.1016/j.jmarsys.2007.03.007, 2008.

Lovegrove, T.: The determination of dry weight of Plankton and the effect of various factors on the values obtained, pp. 429467, Some contemporary studies in Marine Science, Barnes, H. George Allen and Undwin Ltd. London, 1966.

Marty, J.-C.: The DYFAMED time-series program (FrenchJGOFS), Deep-Sea Res. Pt. II, 49, 1963-1964, 2002.

McClatchie, S.: Regional Fisheries Oceanography of the California Current System, The CalCOFI program, Springer, 2013.

MEDOC-Group: Observation of formation of deep water in the Mediterranean Sea, Nature, 227, 1037-1040, 1970.

MEDAR-Group: MEDATLAS 2002 Mediterranean and Black Sea database of temperature, salinity and biochemical parameters climatological atlas, in: 4 CD-ROM, European Commission Marine Science and Technology Programme (MAST), IFREMER, 2002.

Millot, C. and Taupier-Letage, I.: Circulation in the Mediterranean Sea, in: The Mediterranean Sea, vol. 5 part K of The Handbook of Environmental Chemistry, 323-334, Springer Berlin / Heidelberg, doi:10.1007/b107143, 2005.

Packard, T., Minas, H., Coste, B., Martinez, R., Bonin, M., Gostan, J., Garfield, P., Christensen, J., Dortch, Q., Minas, M., CopinMontégut, G., and Copin-Montégut, C.: Formation of the Alboran oxygen minimum zone, Deep-Sea Res., 35, 1111-1118, 1988.

Pai, S.-C., Gong, G.-C., and Liu, K.-K.: Determination of dissolved oxygen in seawater by direct spectrophotometry of total iodine, Mar. Chem., 41, 343-351, 1993.

Puig, P., de Madron, X. D., Salat, J., Schroeder, K., Martín, J., Karageorgis, A. P., Palanques, A., Roullier, F., Lopez-Jurado, J. L., Emelianov, M., Moutin, T., and Houpert, L.: Thick bottom nepheloid layers in the western Mediterranean generated by deep dense shelf water cascading, Prog. Oceanogr., 111, 1-23, doi:10.1016/j.pocean.2012.10.003, 2013.

Rodríguez, J., Álvarez, I., López-Jurado, J. L., García, A., Balbín, R., Álvarez-Berastegui, D., Torres, A., and Alemany, F.: Environmental forcing and the larval fish community in the Balearic region (Western Mediterranean) in early summer 2005, Deep-Sea Res. Pt. I, 77, 11-22, 2013.

Saraiva Nogueira, F. A. and Armando Valladares, J.: Technical Report on Scoping of Operational Oceanography, Tech. rep., Intergovernmental Oceanographic Commission, 2012.

Schroeder, K., Millot, C., Bengara, L., Ben Ismail, S., Bensi, M., Borghini, M., Budillon, G., Cardin, V., Coppola, L., Curtil, C., Drago, A., El Moumni, B., Font, J., Fuda, J. L., García-Lafuente, J., Gasparini, G. P., Kontoyiannis, H., Lefevre, D., Puig, P., Raimbault, P., Rougier, G., Salat, J., Sammari, C., Sánchez Garrido, J. C., Sanchez-Roman, A., Sparnocchia, S., Tamburini, C., Taupier-Letage, I., Theocharis, A., Vargas-Yáñez, M., and 
Vetrano, A.: Long-term monitoring programme of the hydrological variability in the Mediterranean Sea: a first overview of the HYDROCHANGES network, Ocean Sci., 9, 301-324, doi:10.5194/os-9-301-2013, 2013.

Shapiro, H.: Practical flow cytometry, Third Edition, Wiley-Liss, 1995.

Strickland, J. and Parsons, T.: A practical handbook of seawater analysis, Bull. Fish. Res. Board Can., 167, doi:10.1002/iroh.19700550118, 1972.

Treguer, P. and Le Corre, P.: Manuel d'analyse des sels nutritifs dans l'eau de mer. Utilisation de l'AutoAnalyser II Technicon., Occidentale, Univ. Bretagne, Laboratoire de Chimie marine, Brest, France, 1975.

Uttermöhl, H.: On the perfecting of quantitative phytoplankton methods, in: International Association of Theoretical and Applied Limnology/Communications, 9, 1-38, 1958.

Valdés, L., Lavín, A., Fernández de Puelles, M., Varela, M., Anadon, R., Miranda, A., Camiñas, J., and Mas, J.: Spanish Ocean Observation System. IEO Core Project: studies on time series of oceanographic data, Elsevier Oceanography Series, 66, 99-105, 2002.
Vargas-Yáñez, M., Moya, F., García-Martínez, M., Tel, E., Zunino, P., Plaza, F., Salat, J., Pascual, J., Lopez-Jurado, J., and Serra, M.: Climate change in the Western Mediterranean sea 1900-2008, J. Marine Syst., 82, 171-176, doi:10.1016/j.jmarsys.2010.04.013, 2010.

Vargas-Yáñez, M., Zunino, P., Schroeder, K., López-Jurado, J., Plaza, F., Serra, M., Castro, C., García-Martínez, M., Moya, F., and Salat, J.: Extreme Western Intermediate Water formation in winter 2010, J. Marine Syst., 105-108, 52-59, doi:10.1016/j.jmarsys.2012.05.010, 2012.

Zampoukas, N., Piha, H., Bigagli, E., Hoepffner, N., Hanke, G., and Cardoso, A. C.: Monitoring for the Marine Strategy Framework Directive: Requirements and Options, Tech. rep., Joint Research Centre, JRC Scientific anf Technical Reports, 2012. 